\title{
Late cardiac sodium current can be assessed using
}

\section{automated patch-clamp [version 1; peer review: 2 approved]}

\author{
Morgan Chevalier ${ }^{1 *}$, Bogdan Amuzescu ${ }^{2 *}$, Vaibhavkumar Gawali ${ }^{3}$, Hannes Todt ${ }^{3}$, \\ Thomas Knott ${ }^{2}$, Olaf Scheel ${ }^{2}$, Hugues Abriel ${ }^{1,4}$
}

\author{
${ }^{1}$ Department of Clinical Research, University of Bern, Bern, 3010, Switzerland \\ ${ }^{2}$ Cytocentrics Bioscience GmbH, Rostock, 18059, Germany \\ ${ }^{3}$ Medical University of Vienna, Wien, 1090, Austria \\ ${ }^{4}$ Swiss National Centre of Competence in Research (NCCR) TransCure, University of Bern, Bern, 3010, Switzerland \\ ${ }^{*}$ Equal contributors
}

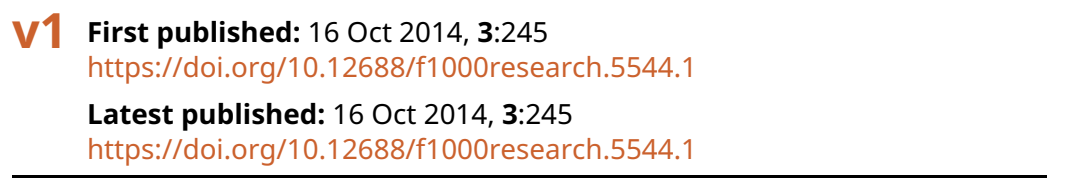

\section{Abstract}

The cardiac late $\mathrm{Na}^{+}$current is generated by a small fraction of voltage-dependent $\mathrm{Na}^{+}$channels that undergo a conformational change to a burst-gating mode, with repeated openings and closures during the action potential (AP) plateau. Its magnitude can be augmented by inactivation-defective mutations, myocardial ischemia, or prolonged exposure to chemical compounds leading to druginduced (di)-long QT syndrome, and results in an increased susceptibility to cardiac arrhythmias. Using CytoPatch ${ }^{\mathrm{TM}} 2$ automated patch-clamp equipment, we performed whole-cell recordings in HEK293 cells stably expressing human Nav1.5, and measured the late $\mathrm{Na}^{+}$component as average current over the last $100 \mathrm{~ms}$ of $300 \mathrm{~ms}$ depolarizing pulses to $-10 \mathrm{mV}$ from a holding potential of $-100 \mathrm{mV}$, with a repetition frequency of $0.33 \mathrm{~Hz}$. Averaged values in different steady-state experimental conditions were further corrected by the subtraction of current average during the application of tetrodotoxin (TTX) $30 \mu \mathrm{M}$. We show that ranolazine at 10 and $30 \mu \mathrm{M}$ in $3 \mathrm{~min}$ applications reduced the late $\mathrm{Na}^{+}$current to $75.0 \pm 2.7 \%$ (mean $\pm \mathrm{SEM}$, $n=17)$ and $58.4 \pm 3.5 \%(n=18)$ of initial levels, respectively, while a 5 min application of veratridine $1 \mu \mathrm{M}$ resulted in a reversible current increase to $269.1 \pm 16.1 \%(n=28)$ of initial values. Using fluctuation analysis, we observed that ranolazine $30 \mu \mathrm{M}$ decreased mean open probability $p$ from 0.6 to 0.38 without modifying the number of active channels $n$, while veratridine $1 \mu \mathrm{M}$ increased $n 2.5$-fold without changing $p$. In human iPSC-derived cardiomyocytes, veratridine $1 \mu \mathrm{M}$ reversibly increased APD90 $2.12 \pm 0.41$-fold (mean \pm SEM, $n=6$ ). This effect is attributable to inactivation removal in Nav1.5 channels, since significant inhibitory effects on hERG current were detected at higher concentrations in hERG-expressing HEK293 cells, with a $28.9 \pm 6.0 \%$ inhibition (mean \pm SD, $n=10$ ) with $50 \mu \mathrm{M}$ veratridine.

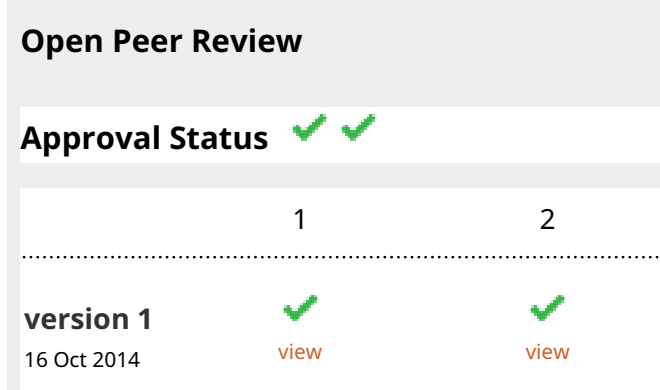

1. Eva Delpon, Universidad Complutense de Madrid, Madrid, Spain

Ricardo Caballero, Universidad Complutense de Madrid, Madrid, Spain

2. Céline Fiset, Université de Montréal, Montréal, Canada

Any reports and responses or comments on the article can be found at the end of the article. 


\section{Keywords}

late $\mathrm{Na}+$ current, veratridine, ranolazine, tetrodotoxin, automated

patch-clamp, action potential, Nav1.5, hERG, iPSC-derived

cardiomyocyte, HEK293

Corresponding author: Hugues Abriel (hugues.abriel@dkf.unibe.ch)

Competing interests: None of the authors has competing interests concerning the present study, except for the participation of TK, OS and BA in the Cytocentrics company.

Grant information: This study was in part funded by a BMBF grant 03WKCC4D, TransCure NCCR Network to HA, and Austrian Science Fund FWF (grant W1232-B11).

The funders had no role in study design, data collection and analysis, decision to publish, or preparation of the manuscript.

Copyright: @ 2014 Chevalier $\mathrm{M}$ et al. This is an open access article distributed under the terms of the Creative Commons Attribution License, which permits unrestricted use, distribution, and reproduction in any medium, provided the original work is properly cited. Data associated with the article are available under the terms of the Creative Commons Zero "No rights reserved" data waiver (CCO 1.0 Public domain dedication).

How to cite this article: Chevalier M, Amuzescu B, Gawali V et al. Late cardiac sodium current can be assessed using automated patch-clamp [version 1; peer review: 2 approved] F1000Research 2014, 3:245 https://doi.org/10.12688/f1 000research.5544.1

First published: 16 Oct 2014, 3:245 https://doi.org/10.12688/f1000research.5544.1 


\section{Introduction}

The late cardiac $\mathrm{Na}^{+}$current can be recorded 10-100 milliseconds after membrane depolarization as a sustained inward current component $\left(I_{\text {sus }}\right)$ in cardiomyocytes ${ }^{1}$. This late current represents a fraction of voltage-dependent $\mathrm{Na}^{+}$channels that fail to inactivate after the initial opening. Instead, these channels change to a conformation with frequent late re-openings in a so-called burst mode ${ }^{2}$. Among other mechanisms, calmodulin kinase II overexpression in chronic heart failure increases the rate of transition to the late bursting mode conformation ${ }^{2}$. The phenomenon is also observed in $\mathrm{Na}_{\mathrm{v}} 1.5$ inactivation-deficient mutants, such as $\triangle \mathrm{KPQ}^{3}$ or $1795 \mathrm{InsD}^{4,5}$, leading to a specific form of congenital long QT syndrome, LQT- ${ }^{6-8}$.

Given its role in cardiac arrhythmogenesis ${ }^{9,10}$, pharmacological inhibition of the late $\mathrm{Na}^{+}$current component $\left(I_{\mathrm{Na} \text { late }}\right)$ is seen as an anti-arrhythmic strategy. Novel late sodium channel blockers, such as the partial fatty acid beta-oxidation inhibitor, ranolazine ${ }^{11-15}$, are used for both myocardial ischemia and to alleviate neuropathic pain and show a preferential affinity for the burst mode conformation of $\mathrm{Na}^{+}$channels ${ }^{16-21}$. Other compounds, such as veratridine, a steroidderived alkaloid extracted from rhizomes of Veratrum album or seeds of Schoenocaulon officinale ${ }^{22,23}$, preferentially bind to activated $\mathrm{Na}^{+}$channels, impeding inactivation and leading to increased nerve excitability.

The objectives of this study were to (1) record the veratridinedependent increase in the late $\mathrm{Na}^{+}$current using a HEK293 cell line stably transfected with human $\mathrm{Na}_{\mathrm{v}} 1.5^{24}$, (2) measure the ranolazineinduced inhibition of basal and veratridine-activated $I_{\text {Nalate }}$, and (3) asses the effects of veratridine at the same concentrations on action potentials (APs) in hiPSC-cardiomyocyte preparations externally paced in current-clamp mode. In parallel we also tested the inhibitory effects of veratridine on hERG1 current in stably transfected HEK293 cells. All these experiments were performed using CytoPatch ${ }^{\mathrm{TM}} 2$ automated patch-clamp equipment.

\section{Materials and methods}

All experiments were performed using the CytoPatch ${ }^{\mathrm{TM}} 2$, using standard dual-channel Cytocentrics chips with embedded quartz pipette tips $2 \mu \mathrm{M}$ in diameter. For whole-cell late $\mathrm{Na}^{+}$current recordings, the voltage-clamp protocol consisted of repeated depolarizing pulses of $-10 \mathrm{mV}$ amplitude and $300 \mathrm{~ms}$ duration, from a holding potential of $-100 \mathrm{mV}$, to allow a substantial removal from inactivation of $\mathrm{Na}_{\mathrm{v}} 1.5$ channels. The peak and late $\mathrm{Na}^{+}$current were plotted and monitored over the entire duration of experiment, and extracted from recorded data for further analysis. Pharmacological compounds were applied in a predefined sequence using the dispensing needle of automated equipment. All experiments were performed at room temperature $\left(21-22^{\circ} \mathrm{C}\right)$.

For whole-cell hERG current recordings, cells were held at $-70 \mathrm{mV}$. After a brief $100-\mathrm{ms}$ prepulse to $-50 \mathrm{mV}$ to determine the current leak, a 2-s depolarizing voltage step to $+40 \mathrm{mV}$ was followed by a 2 -s step to $-50 \mathrm{mV}$ to elicit hERG tail currents every $10 \mathrm{~s}$. Peak tail current amplitude was corrected by the leak current and the corrected peak tail current was averaged over the last three pulses of the control phase $\left(I_{\text {ctrl }}\right)$ and the application phase $\left(I_{\mathrm{cpd}}\right)$, respectively.
From these averaged values the hERG tail current inhibition was calculated as follows:

$$
\text { Inhibition }=1-\left(I_{\mathrm{cpd}} / I_{\mathrm{ctrr}}\right)
$$

iPSC-CM recordings were performed in current-clamp mode, using repeated sweeps consisting of 3 injected current pulses of $2000 \mathrm{pA}$ amplitude, $0.5 \mathrm{~ms}$ duration, at 3 -s intervals. During solution uptake the system was switched to voltage-clamp mode.

\section{Cell cultures and preparations}

HEK293 cells stably expressing either the human $\mathrm{Na}_{\mathrm{v}} 1.5$ channel or the hERG $\mathrm{K}^{+}$channel were used as ready-to-use frozen Instant cells (product of Cytocentrics). Cells, kept in liquid nitrogen, were quickly thawed, centrifuged, resuspended in extracellular solution at a density of $\sim 10^{6}$ cells $/ \mathrm{ml}$, and used for experiments within 3 hours. For other experiments, Nav1.5-expressing cells were cultured in $25 \mathrm{~cm}^{2}$ flasks in DMEM supplemented with $10 \%$ fetal bovine serum and $100 \mu \mathrm{g} / \mathrm{ml}$ zeozin, and kept at $37^{\circ} \mathrm{C}, 8 \% \mathrm{CO}_{2}$ in a humidified incubator. Adherent cell monolayers were detached with Versene (ethylenediaminotetraacetic acid - EDTA $0.02 \%$ in phosphate buffered saline - PBS), centrifuged for $2 \mathrm{~min}$ at $100 \times \mathrm{g}$, and resuspended in hERG external solution.

hiPSC-derived iCell ${ }^{\circledast}$ Cardiomyocytes were kindly provided by Cellular Dynamics International (Madison, WI) as frozen samples, and cultured in monolayers in 12 -well plates coated with $0.1 \%$ gelatin, for up to 41 days. The thawing/plating and maintenance media were provided by the cell supplier. For detachment, the monolayers were rinsed twice with calcium and magnesium-free PBS, then incubated for $2 \mathrm{~min}$ with trypsin $0.1 \%$ at $37^{\circ} \mathrm{C}$. $1.5 \mathrm{ml}$ of medium was added per well, the cells were suspended, centrifuged at $180 \times \mathrm{g}$ for $5 \mathrm{~min}$, and resuspended in a 1:1 mixture of culture medium and hERG extracellular solution.

\section{Solutions and chemicals}

For recordings in $\mathrm{Na}_{\mathrm{v}} 1.5$-transfected HEK293 cells the external solution had the following composition (in $\mathrm{mM}$ ): $\mathrm{NaCl} 130, \mathrm{CsCl} 5$, $\mathrm{CaCl}_{2} 2, \mathrm{MgCl}_{2}$ 1.2, HEPES 10, D-glucose 5, pH 7.4, osmolality $320 \mathrm{mOsm} / \mathrm{kg}$. The internal solution contained (in mM): Cs-aspartate 70, $\mathrm{CsCl} 60, \mathrm{CaCl}_{2} 1, \mathrm{MgCl}_{2}$ 1, $\mathrm{Na}_{2}$ ATP 5, EGTA 11, HEPES 10, pH 7.2 with $\mathrm{CsOH}$, osmolality $290 \mathrm{mOsm} / \mathrm{kg}$. For recordings in iPSC-derived cardiomyocytes and hERG-transfected HEK293 cells the extracellular solution had the following composition (in $\mathrm{mM}$ ): $140 \mathrm{NaCl}, 2.5 \mathrm{KCl}, 2 \mathrm{MgCl}_{2}, 2 \mathrm{CaCl}_{2}, 10$ HEPES, 10 Glucose, 15 Sucrose. The $\mathrm{pH}$ was adjusted to 7.4 with $\mathrm{NaOH} 1 \mathrm{M}$ and the osmolality to $320( \pm 5) \mathrm{mOsmol} / \mathrm{kg}$ with sucrose $1 \mathrm{M}$, and the storage temperature was $4^{\circ} \mathrm{C}$. The intracellular solution contained (in $\mathrm{mM}$ ): $100 \mathrm{~K}$ Gluconate, $20 \mathrm{KCl}, 1 \mathrm{CaCl}_{2}, 1 \mathrm{MgCl}_{2}, 10 \mathrm{HEPES}, 11$ EGTA$\mathrm{KOH}, 4$ ATP- $\mathrm{Mg}^{2+}, 3$ Phosphocreatine- $\mathrm{Na}_{2}-\mathrm{H}_{2} \mathrm{O}, 9$ Sucrose. The $\mathrm{pH}$ was adjusted to 7.2 with $\mathrm{KOH} 1 \mathrm{M}$, the osmolality to $295( \pm 5)$ $\mathrm{mOsmol} / \mathrm{l}$, and then it was stored in $10-\mathrm{ml}$ aliquots at $-20^{\circ} \mathrm{C}$, thawed and used within 4 hours. Veratridine (Sigma V5754) working solutions at 1,5 and $50 \mu \mathrm{M}$ were prepared from a $50 \mathrm{mM}$ stock solution in ethanol. Ranolazine dihydrochloride (Sigma R6152) 10 and $30 \mu \mathrm{M}$ was prepared from a $10 \mathrm{mM}$ stock solution in DMSO. TTX (BN0518, Biotrend, Zurich, $\mathrm{CH}$ ) was prepared from a $1 \mathrm{mM}$ aqueous stock solution. 


\section{Data storage and analysis}

The software files generated during the recordings were stored on computer hard disks. Patch clamp data were analyzed using the CytoPatch $^{\mathrm{TM}}$ software and exported to Microsoft Excel or pClamp10 (Axon Instruments, part of Molecular Devices, Sunnyvale, CA) for further analysis, using a proprietary conversion tool. APD90 analysis for current-clamp recordings in iPSC-derived cardiomyocytes was performed with self-written software routines. APD90 was computed as the duration between the point of maximal AP upstroke speed during phase 0 to recovery of $90 \%$ of the difference between peak upstroke potential and resting potential. In the case of veratridine application, if recovery was incomplete during the 3-s interstimulus interval, APD90 was computed over several pacing cycles. For statistical analysis, one-way ANOVA for independent samples with Dunnett's post-hoc comparison, as well as Student's $t$ tests where appropriate, were applied, at a level of significance of $p \leq 0.05$, using the GraphPad Prism software (La Jolla, CA).

\section{Results}

\section{Late Nav1.5 sodium current component}

Using automated voltage-clamp protocols applied to human Nav1.5expressing HEK293 cells in the above mentioned conditions, we routinely recorded, in high-quality seal conditions (both seal and membrane resistance $>1 \mathrm{G} \Omega$ ), and with stability for at least $20 \mathrm{~min}$, whole-cell $\mathrm{Na}^{+}$currents. These currents were elicited by membrane depolarization to $-10 \mathrm{mV}$ from a holding potential of $-100 \mathrm{mV}$, required for the proper removal from inactivation of cardiac $\mathrm{Na}^{+}$ channels. The late $\mathrm{Na}^{+}$current component $\left(I_{\mathrm{Na} \text { late }}\right)$ was automatically computed and plotted as time average over the last $100 \mathrm{~ms}$ of the 300-ms depolarizing pulse of each sweep. Figure 1A shows the time course of 5 averaged experiments including repeated applications of veratridine $1 \mu \mathrm{M}$ with different durations ( $2 \mathrm{~min}, 1 \mathrm{~min}$, $5 \mathrm{~min}$ ), as well as a 1 -min application of TTX $30 \mu \mathrm{M}$, resulting in the rapid complete block of late $\mathrm{Na}^{+}$current. The average current level during TTX application in each experiment was subsequently subtracted from all other averaged steady-state levels to obtain unbiased estimations of $I_{\mathrm{Na} \text { late }}$ in different experimental conditions. In general, reversibility was good and rapid upon TTX wash-out.

\section{Late sodium current activation by veratridine and block by ranolazine in Nav1.5 cells}

Under control conditions, a 5-min application of veratridine $1 \mu \mathrm{M}$ induced an increase of the late $\mathrm{Na}^{+}$current by $269.1 \pm 16.1 \%$ (mean \pm SEM, $n=28$ ) of initial values (Table 1 and Figure 2). Figure 1B shows representative current traces of selected sweeps, as well as

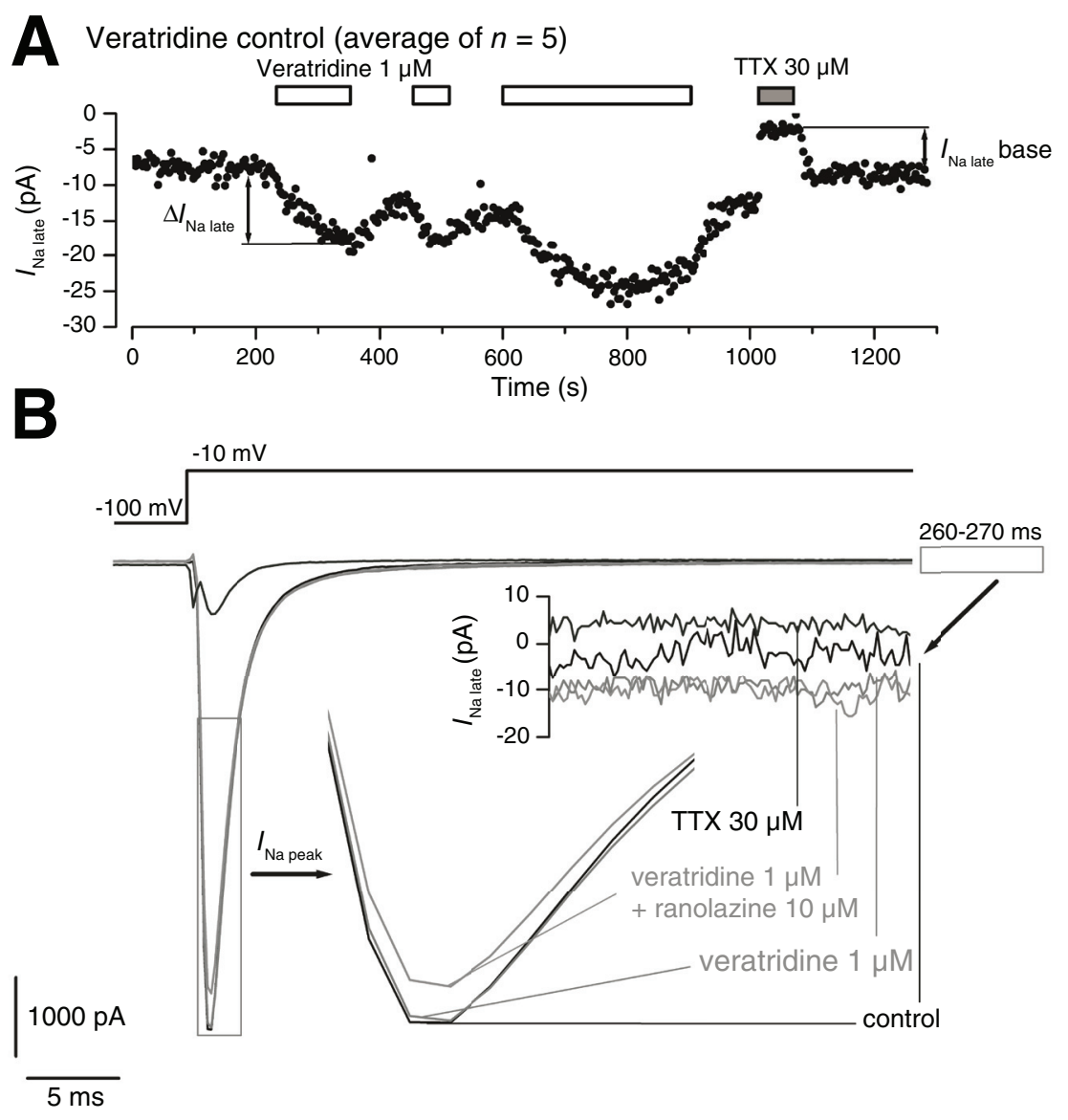

Figure 1. Activation by veratridine of the late $\mathrm{Na}^{+}$current in Nav1.5-expressing cells. A. Time course of $I_{\text {Na late }}$ (average transmembrane current during the last $100 \mathrm{~ms}$ of a $300-\mathrm{ms}$ depolarizing pulse to $-10 \mathrm{mV}$ from a holding potential of $-100 \mathrm{mV}$ ) during a typical experiment with repeated applications of veratridine $1 \mu \mathrm{M}$ and a final application of TTX $30 \mu \mathrm{M}$. B. Overlap of individual sweeps showing the peak and late component of $I_{\mathrm{Na}}$ during the application of veratridine $1 \mu \mathrm{M}$, the co-application with ranolazine $10 \mu \mathrm{M}$, and with TTX $30 \mu \mathrm{M}$. The peak and late $I_{\mathrm{Na}}$ component are shown separately in inserts using magnified time and voltage scales, respectively. 
Table 1. Effects of ranolazine 10 and $30 \mu \mathrm{M}$ and veratridine $1 \mu \mathrm{M}$ on TTX-sensitive* late $\mathrm{Na}^{+}$current.

\begin{tabular}{|c|c|c|c|c|c|c|c|c|}
\hline \multirow{2}{*}{$\begin{array}{l}\text { Experiment } \\
\text { Drug application } \\
\text { ( } n=\text { number of cells tested) }\end{array}$} & \multicolumn{3}{|c|}{$\begin{array}{l}\text { Absolute values } \\
\text { (mean } \pm \text { SEM) }\end{array}$} & \multicolumn{5}{|c|}{$\begin{array}{l}\text { Relative values } \\
\text { (mean } \pm \text { SEM) }\end{array}$} \\
\hline & $\begin{array}{l}\boldsymbol{I}_{\text {Na late initial }} \\
\quad(\mathrm{pA})\end{array}$ & $\begin{array}{l}\boldsymbol{I}_{\text {Na late }} \text { drug } \\
\quad(\mathrm{pA})\end{array}$ & $\begin{array}{l}\boldsymbol{I}_{\mathrm{Na} \text { late final }} \\
\quad(\mathrm{pA})\end{array}$ & $\begin{array}{l}\boldsymbol{I}_{\text {Na late }} \text { initial } \\
(\%)\end{array}$ & $\begin{array}{l}\boldsymbol{I}_{\mathrm{Na}} \text { late } \text { drug } \\
(\%)\end{array}$ & $\begin{array}{l}\boldsymbol{p} \text { value } \\
\text { vs. initials }\end{array}$ & $\begin{array}{l}I_{\text {Na late final }} \\
(\%)\end{array}$ & $\begin{array}{l}\boldsymbol{p} \text { value } \\
\text { vs. initials }\end{array}$ \\
\hline $\begin{array}{l}\text { Ranolazine } 10 \mu \mathrm{M} 3 \mathrm{~min} \\
(n=17)\end{array}$ & $-13.2 \pm 2.6$ & $-9.7 \pm 1.8$ & $-13.2 \pm 2.3$ & 100 & $75.0 \pm 2.7$ & 7.8E-8 & $105.6 \pm 5.0$ & 0.280 \\
\hline $\begin{array}{l}\text { Ranolazine } 30 \mu \mathrm{M} 3 \mathrm{~min} \\
(n=18)\end{array}$ & $-10.6 \pm 2.2$ & $-6.1 \pm 1.4$ & $-11.9 \pm 2.8$ & 100 & $58.4 \pm 3.5$ & 1.1E-9 & $107.7 \pm 7.7$ & 0.330 \\
\hline $\begin{array}{l}\text { Veratridine } 1 \mu \mathrm{M} 5 \mathrm{~min} \\
(n=28)\end{array}$ & $-12.4 \pm 1.9$ & $-36.3 \pm 6.7$ & $-15.8 \pm 2.7$ & 100 & $269.1 \pm 16.1$ & 4.7E-11 & $114.2 \pm 8.2$ & 0.095 \\
\hline
\end{tabular}

" I Na ate values were computed by subtraction of averaged amplitude in the presence of TTX $30 \mu \mathrm{M}$ from averaged amplitudes in all other experimental conditions

$\S$ using two-tailed Student's $t$ test for paired samples
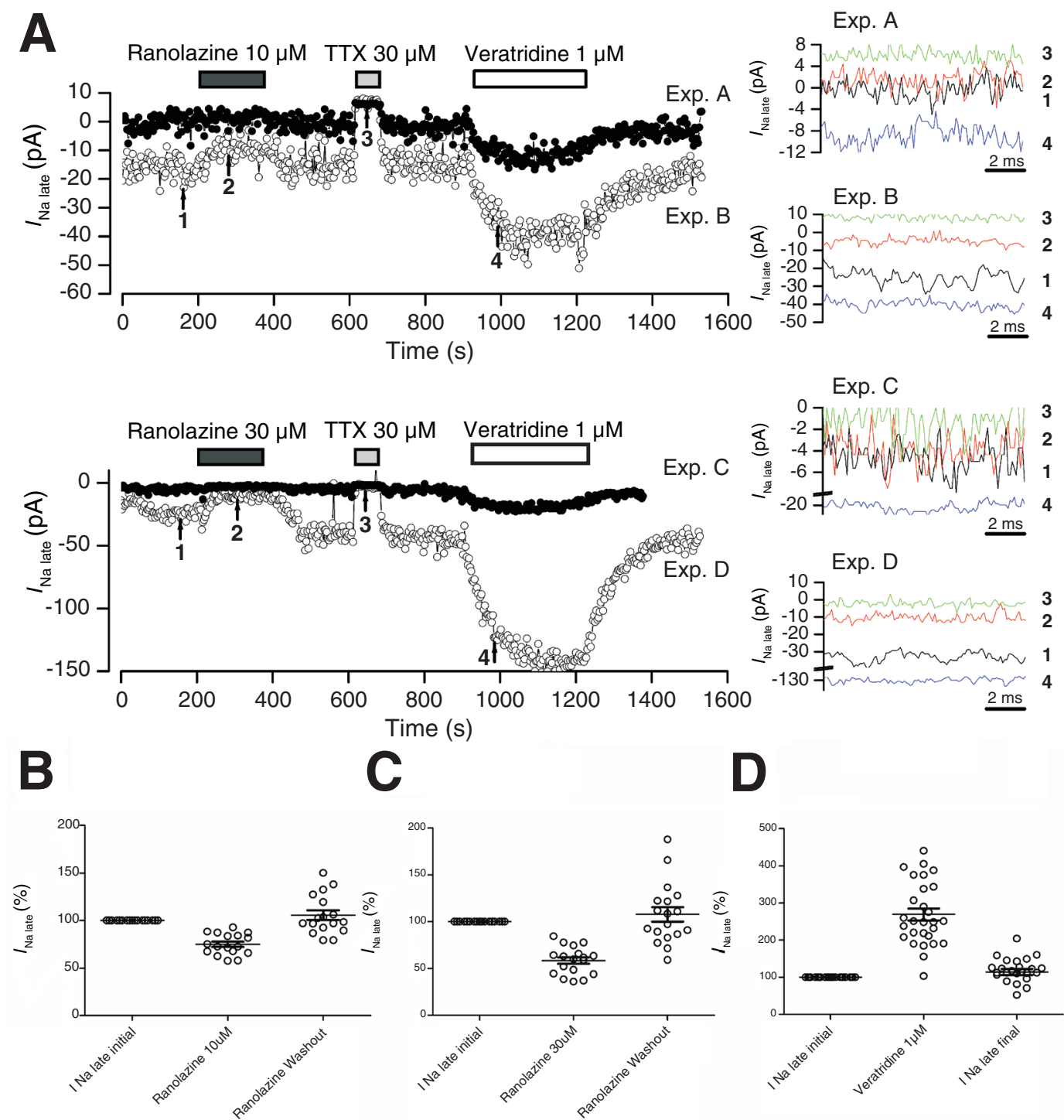

Figure 2. Effects of ranolazine, TTX and veratridine on the late $\mathrm{Na}^{+}$current in Nav1.5-expressing cells. A. Time plots of $I_{\text {Na late }}$ in four typical experiments. Intervals of application of ranolazine 10 or $30 \mu \mathrm{M}$, TTX $30 \mu \mathrm{M}$, and veratridine $1 \mu \mathrm{M}$ are indicated. Right panels: I Nalate traces from 260 to $270 \mathrm{~ms}$ at the time points marked with arrows and numbered in the left panels. B and C. Effects of ranolazine 10 and $30 \mu \mathrm{M}$, respectively, on relative levels of TTX-sensitive late $\mathrm{Na}^{+}$current. D. Effect of veratridine $1 \mu \mathrm{M}$. Mean values are indicated for each condition, and error bars represent SEM. 
magnified inserts of the peak and late phase, within an individual experiment. The application of veratridine $1 \mu \mathrm{M}$ increased the late current amplitude by more than two-fold relative to the TTX $30 \mu \mathrm{M}$ reference trace, without any noticeable effect on peak current, while the co-application of ranolazine $10 \mu \mathrm{M}$ reduced the peak current with apparently no effect on the late component. Systematic experiments with ranolazine applied alone demonstrated $I_{\mathrm{Na} \text { late }}$ reduction to $75.0 \pm 2.7 \%$ (mean $\pm \mathrm{SEM}, n=17$ ) of initial values at $10 \mu \mathrm{M}$, and $58.4 \pm 3.5 \%$ (mean \pm SEM, $n=18$ ) at $30 \mu \mathrm{M}$ (Table 1 and Figure 2).

Figure 3 shows the power density spectra of Fourier-transformed traces recorded under different conditions, as numbered in the upper time course of the experiments. Presumably, the opening and closure of Nav1.5 channels in the late gating mode conformation produces a Lorentzian component with corner frequency above $2 \mathrm{KHz}$. However, due to the reduced number of individual signal sources, the plateau spectral power density was small and difficult to distinguish. A better approach to fluctuation analysis is by the computation of single-channel parameters such as the mean open probability $p$ and the average number of channels $n$, starting from the well-known estimations of current variance $\sigma^{2}$ and macroscopic current $I^{25}$ :

$$
\sigma^{2}=n p i^{2}-n p^{2} i^{2}=n p(1-p) i^{2} \text { and } I=n p i
$$

We used a unitary $\mathrm{Na}^{+}$current amplitude $i$ at $-10 \mathrm{mV}$ of $1.43 \mathrm{pA}$, based on the unitary current amplitude of $2 \mathrm{pA}$ at $-40 \mathrm{mV}$ observed in single-channel recordings of Nav1.5 late currents in HEK293 cells ${ }^{26}$ and a reversal potential of $+65 \mathrm{mV}$. In doing so, we could evaluate the mean open probability $p$ and further the average number of $\mathrm{Na}^{+}$channels $n$ open in the late mode in selected traces, over the last $100 \mathrm{~ms}$ of activity during the 300-ms depolarizing pulses. It was observed that $30 \mu \mathrm{M}$ ranolazine application resulted in a decrease of mean open probability from 0.6 to 0.38 , without affecting the average number of channels contributing the late $\mathrm{Na}^{+}$ current $(n=4)$, in agreement with estimates obtained from averaged macroscopic currents. On the other hand, veratridine $1 \mu \mathrm{M}$ increased the number of channels in late gating mode to $n=10$, without influencing the mean open probability.

\section{3. di-APD prolongation in iPSC-CM by application of veratridine}

To get a better understanding of the role that the late $\mathrm{Na}^{+}$current may play in arrhythmogenesis and in the complex mechanisms of di-LQT syndrome, we performed a series of automated patch-clamp

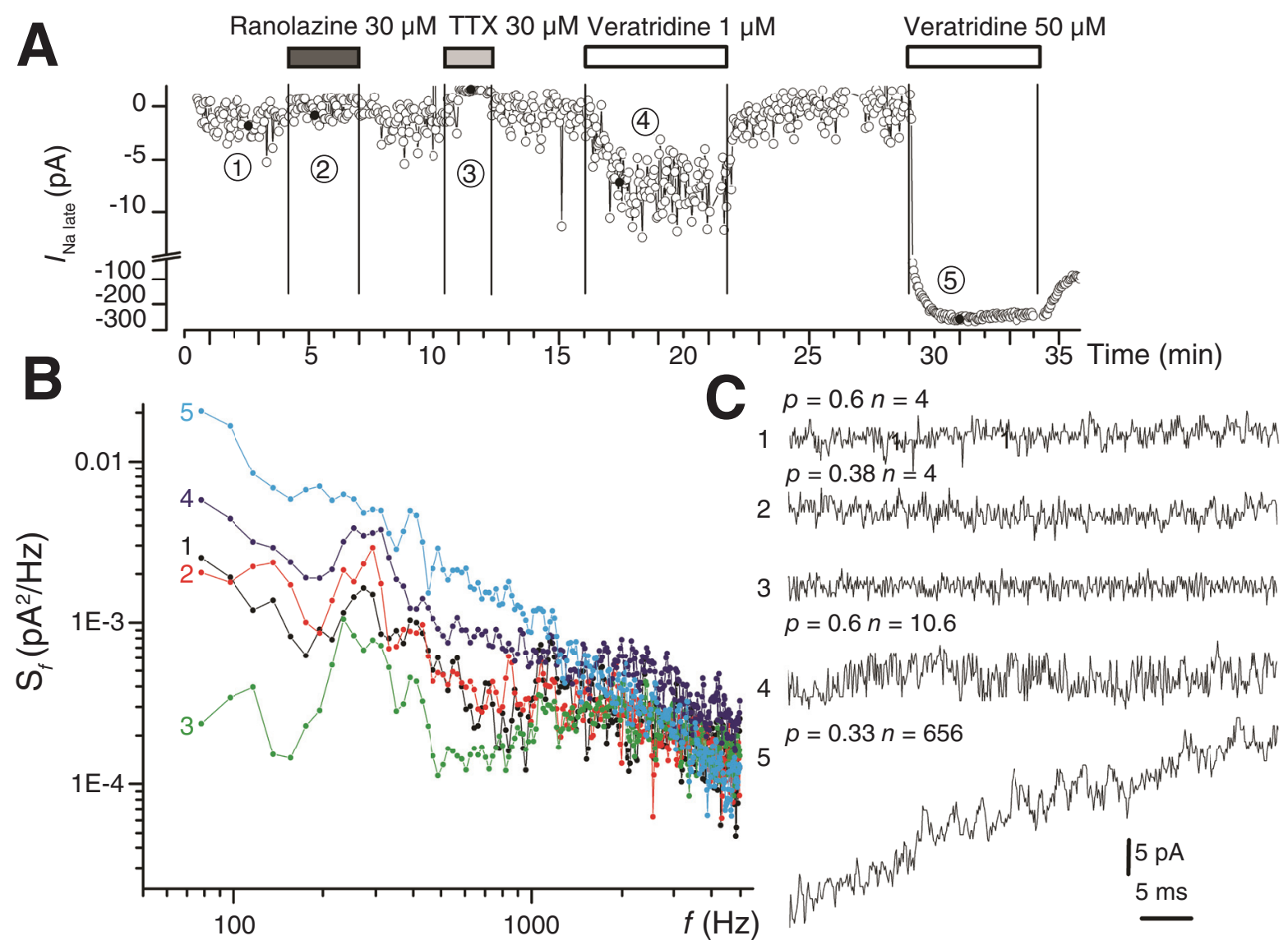

Figure 3. The late $\mathrm{Na}^{+}$current presents fluctuations due to the opening and closure of individual channels. A. Time course of a typical experiment in Nav1.5-expressing cells showing the effects of ranolazine $30 \mu \mathrm{M}$, TTX $30 \mu \mathrm{M}$, and veratridine $1 \mu \mathrm{M}$ on $I_{\text {Nalate }}$. B. Averaged Fourier transforms of multiple traces recorded in different conditions in the experiment shown in A: 1 . initial control; 2 . ranolazine $30 \mu \mathrm{M} ; 3$. TTX 30 $\mu \mathrm{M} ; 4$. veratridine $1 \mu \mathrm{M} ; 5$. veratridine $50 \mu \mathrm{M}$. C. Fluctuation analysis of individual traces recorded during the five distinct periods shown in $\mathbf{A}$ allowed the distinction of individual channel gating events and the computation of the average open probability $p$ and the average number of channels $n$ for each condition. 
experiments on hiPSC-derived cardiomyocytes with current-clamp recordings of stimulus-triggered APs. Each recorded sweep contained responses elicited by three injected current stimuli $(0.5 \mathrm{~ms}$ duration, $2 \mathrm{nA}$ amplitude). As shown in Figure 4, veratridine $1 \mu \mathrm{M}$ induced a marked prolongation of AP duration, reaching saturation in less than $3 \mathrm{~min}$. Further application of $5 \mu \mathrm{M}$ veratridine resulted in further APD90 prolongation, exceeding the interstimulus interval. There was a slow trend to reversibility during the wash-out phase. Quantitative results for veratridine $1 \mu \mathrm{M}$ application are summarized in Table 2. Thus, in $n=6$ experiments at room temperature the relative APD90 prolongation induced by veratridine was $2.12 \pm 0.41$ fold (mean \pm SEM), reversible to $1.21 \pm 0.50$ fold at wash-out (mean \pm SEM, $n=4$ ).

\section{Weak hERG inhibition by veratridine}

Last, we performed experiments using HEK293 cells stably expressing hERG1 to assess the effects of veratridine at different concentrations on this current component, in order to better understand the complex effects of this compound on the action potential of iPSC-derived cardiomyocytes. As shown in Figure 5, veratridine concentrations up to $5 \mu \mathrm{M}$ did not produce levels of hERG inhibition significantly different than the diluting vehicle alone (ethanol $0.1 \%$ ), while at $50 \mu \mathrm{M}$ there was a $28.9 \pm 6.0 \%$ (mean \pm SD, $n=10$ ) inhibition of peak hERG current, a statistically significant effect ( $p<0.0001$, one-way ANOVA for independent samples with Dunnett's multiple comparison test $v s$. control).

Dataset 1. Experimental data showing the effect of veratridine, ranolazine and TTX on late $\mathrm{Na}^{+}$currents in cultured cells

http://dx.doi.org/10.5256/f1000research.5544.d36993

Patch-clamp data showing the effects on late $\mathrm{Na}^{+}$current after veratridine, ranolazine and TTX treatment in Nav1.5-expressing HEK293 cells, the effect of veratridine on hERG currents and on externally paced action potentials in iCell ${ }^{\circledR}$ Cardiomyocytes assessed with CytoPatch ${ }^{\mathrm{T}} 2$ automated patch-clamp equipment. For more details, please see the legend file in Dataset 1.

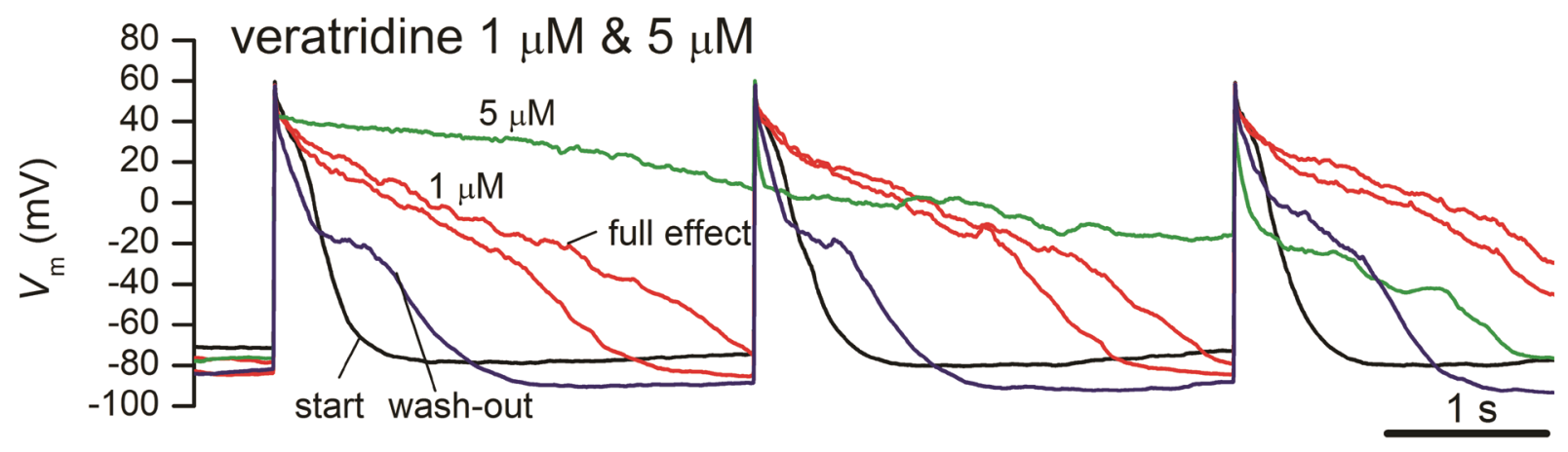

Figure 4. AP prolongation by veratridine in human iPSC-derived cardiomyocytes. Current-clamp AP recordings using a pacing protocol with injected current stimuli of 0.5-ms duration and $2 \mathrm{nA}$ amplitude repeated at 3-s intervals. The overlap of traces in control conditions at the start of the experiment, with $1 \mu \mathrm{M}$ veratridine (onset and full effect), with $5 \mu \mathrm{M}$ veratridine, and during wash-out, shows partial recovery.

\begin{tabular}{|c|c|c|c|c|c|}
\hline $\begin{array}{l}\text { Experimental } \\
\text { condition }\end{array}$ & $\begin{array}{l}\text { APD90 } \\
\text { initial }\end{array}$ & $\begin{array}{c}\text { APD90 } \\
\text { during appl. }\end{array}$ & $\begin{array}{c}\text { APD90 } \\
\text { wash-out }\end{array}$ & $\begin{array}{c}\text { Relative APD90 } \\
\text { during appl. }\end{array}$ & $\begin{array}{c}\text { Relative APD90 } \\
\text { wash-out }\end{array}$ \\
\hline Veratridine $1 \mu \mathrm{M}$ & $777.5 \pm 179.1$ & $1429.3 \pm 289.8$ & $688.0 \pm 86.9$ & $2.12 \pm 0.41$ & $1.21 \pm 0.50$ \\
\hline$p$ & & 0.02482 & 0.65037 & & \\
\hline$n$ & 6 & 6 & 4 & 6 & 4 \\
\hline $\begin{array}{l}\text { Ethanol } 0.1 \% \\
\text { control }\end{array}$ & $893.8 \pm 343.8$ & $1013.0 \pm 408.4$ & $917.3 \pm 318.3$ & $1.08 \pm 0.07$ & $1.17 \pm 0.17$ \\
\hline$p$ & & 0.16664 & 0.75986 & & \\
\hline$n$ & 4 & 4 & 4 & 4 & 4 \\
\hline
\end{tabular}

Relative values are computed taking initial values as reference $p$ values for Student's $t$ test for paired samples, two-tailed, for condition tested $v s$. initial values $n=$ number of cells included in analysis 


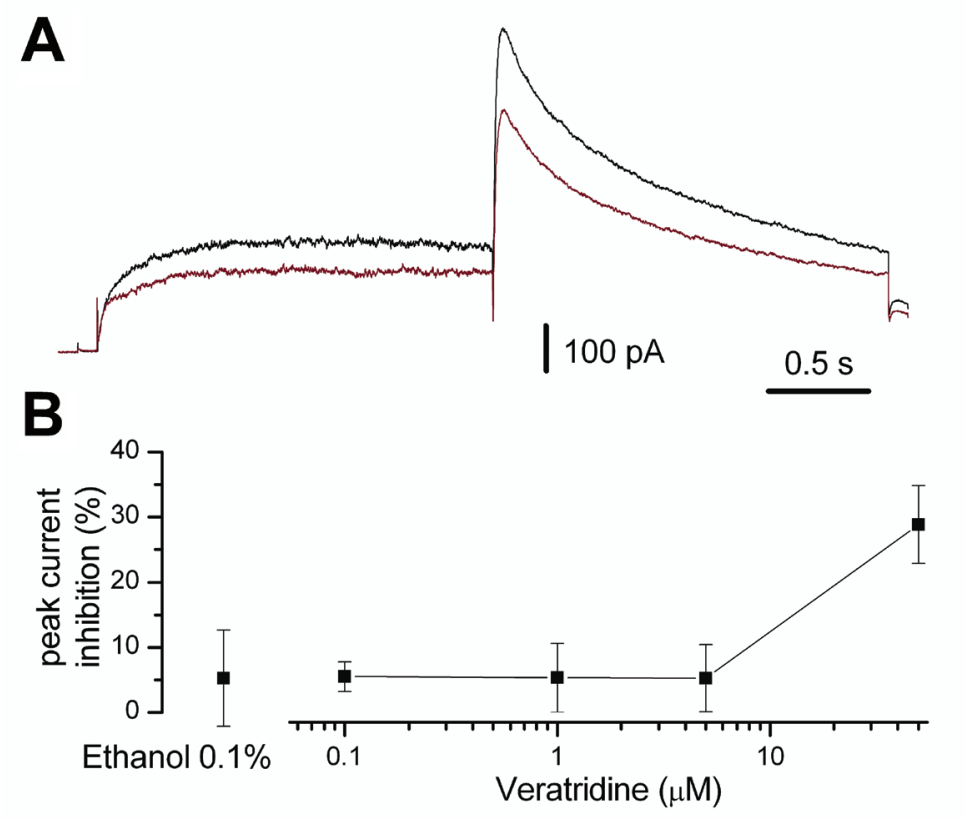

Figure 5. Effects of veratridine on hERG channels. A. Current traces in control conditions (upper) and during application of veratridine $50 \mu \mathrm{M}$ (lower trace). B. Percentages of peak hERG current inhibition by different concentrations of veratridine and control ethanol $0.1 \%$ vehicle. Error bars represent SD. Number of experiments: control $(n=6)$, veratridine $0.1 \mu \mathrm{M}(n=10), 1 \mu \mathrm{M}(n=5), 5 \mu \mathrm{M}(n=7), 50 \mu \mathrm{M}(n=10)$.

\section{Discussion}

The main findings of the present study using the CytoPatch ${ }^{\mathrm{TM}} 2$ instrument are the following: (1) inhibition of cardiac late $\mathrm{Na}^{+}$current to $75.0 \%$ and $58.4 \%$ of initial values by ranolazine 10 and $30 \mu \mathrm{M}$, respectively; (2) activation of the same current by veratridine $1 \mu \mathrm{M}$ to $269.1 \%$ of initial values; and (3) prolongation of APD90 by veratridine $1 \mu \mathrm{M}$ to $212 \%$ of initial values in human iPSC-derived cardiomyocytes. We have succeeded in recording and analysing the small (a few picoA) late $\mathrm{Na}^{+}$current component in a human cell line stably transfected with wild-type human SCN5A, using automated patch-clamp technology, with a voltage protocol different from that used in the first electrophysiology characterization of $\triangle \mathrm{KPQ} L Q T-3$ mutant $\mathrm{Na}^{+}$channels ${ }^{3}$. We observed that instrumental noise does not significantly affect the average current value over the last $100 \mathrm{~ms}$ of a $300-\mathrm{ms}$ depolarizing pulse from -100 to $-10 \mathrm{mV}$, therefore this value can be computed and plotted in real-time, representing a sensitive indicator for evidencing pharmacological effects in automated patch-clamp assays. Another critical parameter is the frequency of repetition of depolarizing stimuli, because it may reveal use dependency for compounds exerting state-dependent binding effects $^{27}$. Although in the present set of experiments we kept a fixed value of $0.33 \mathrm{~Hz}$, inclusion of different pacing rates in future variants of the assay may offer supplementary information of pharmacological relevance. An important tool in the precise assessment of $I_{\mathrm{Na}}$ late levels is the application of TTX $30 \mu \mathrm{M}$, which results in an almost complete late $\mathrm{Na}^{+}$current inhibition, and offers a current reference used for the correction by subtraction of all other values in different experimental conditions. An excellent seal stability and access resistance, such as those offered by the Cytocentrics microfluidic chips ${ }^{28}$, is another prerequisite for successful late $\mathrm{Na}^{+}$pharmacology experiments.
Due to the limited amplitude of late $\mathrm{Na}^{+}$current under basal conditions, we increased it using low concentrations of veratridine, a steroid-derived natural alkaloid known to bind to an intramembrane site of $\mathrm{Na}^{+}$channel pore subunits and, in doing so, stabilize it in the open conformation ${ }^{29,30}$, contributing to the $I_{\text {Na late }}$. Although veratridine at $1 \mu \mathrm{M}$ resulted in a consistent $2.5-3$-fold increase in late $\mathrm{Na}^{+}$current, compared to initial levels (Table 1 and Figure $1-$ Figure 3), we would not recommend this procedure for pharmacology assays because of possible interactions between veratridine and test compounds. Although we have not systematically explored this phenomenon, preliminary observations, as shown in Figure 1B, suggest a reduced effectiveness of ranolazine $10 \mu \mathrm{M}$ when co-applied with veratridine, compared to application of ranolazine alone at the same concentration. The value of relative inhibition of the late $\mathrm{Na}^{+}$current by ranolazine $10 \mu \mathrm{M}$ in the single compound application obtained in our study (75.0\% of control levels) is larger than those obtained with the same concentration of ranolazine on late $\mathrm{Na}^{+}$current activated by veratridine $40 \mu \mathrm{M}(89 \%$ and $81 \%$ for holding potentials of $-110 \mathrm{mV}$ and $-90 \mathrm{mV}$, respectively) ${ }^{31}$. An elegant method that may offer pharmacologically relevant information concerning the site and mechanism of action of a certain compound is fluctuation analysis. As shown in Figure 3, when applied to selected traces, this method allows the computation of the mean open probability $p$ and the average number of open channels $n$ contributing to current variance. From this analysis, we hypothesize that ranolazine acts as an open pore blocker, reducing the mean open probability at $30 \mu \mathrm{M}$ to $63 \%$ of initial values, from 0.6 to 0.38 , without lowering the number of active channels, while veratridine $1 \mu \mathrm{M}$ increases the number of active channels in late gating mode 2.5 -fold, without influencing their mean open probability. 
In agreement with the significant activatory effects of veratridine $1 \mu \mathrm{M}$ on cardiac Nav1.5 channels in late gating mode in stably transfected cell lines, we found an important prolongation of action potential duration when the drug was applied to human iPSCderived cardiomyocytes in current-clamp configuration, using CytoPatch $^{\mathrm{TM}} 2$ automated patch-clamp equipment. The APD90 was increased over twofold by veratridine $1 \mu \mathrm{M}$, with a good reversibility upon wash-out (Table 2), and an even higher prolongation with $5 \mu \mathrm{M}$ (Figure 4), although in this case we were unable to accurately compute APD90 values for externally paced APs, due to their overlap with the next stimulus. This effect is consistent with the findings of previous studies, showing APD prolongation in bronchial smooth muscle cells upon veratridine application ${ }^{32}$, and the enhancement of AP burst generation by veratridine in rat trigeminal sensory neurons ${ }^{33}$. Furthermore, we have demonstrated that hERG inhibition does not play any role in the observed APD prolongation by veratridine at 1 or $5 \mu \mathrm{M}$, since significant hERG inhibition occurred with higher veratridine concentrations (Figure 5). A recent combined in vivo and in vitro study proved that the augmentation of the myocardial late $\mathrm{Na}^{+}$current during ventricular remodeling induced by pulmonary arterial hypertension in rats was accompanied by significant APD90 increases, and a beneficial effect of repeated ranolazine administration via late $\mathrm{Na}^{+}$current block was demonstrated with a subsequent alleviation of induced intracellular $\mathrm{Ca}^{2+}$ overload $^{34}$.

In conclusion, the present study demonstrates that automated patchclamp, as implemented by the CytoPatch ${ }^{\mathrm{TM}} 2$ equipment using our proprietary CYTOCENTERING technology and quartz pipette tips embedded in silicon microfluidic chips ${ }^{28,35}$, which allow highquality stable seals, lead to reliable late $\mathrm{Na}^{+}$current pharmacology recordings, with results at least comparable to those obtained in manual patch-clamp experiments. In addition, automation may prove advantageous given the small amplitude of late $\mathrm{Na}^{+}$current, which therefore requires a large number of experiments for the accurate assessment of pharmacological effects.

\section{Data availability}

F1000Research: Dataset 1. Experimental data showing the effect of veratridine, ranolazine and TTX on late $\mathrm{Na}^{+}$currents in cultured cells, 10.5256/f1000research.5544.d36993 $3^{36}$

\footnotetext{
Abbreviations

HEK: human embryo kidney

CHO: Chinese hamster ovary
}

hERG: human ether-á-go-go related gene

SEM: standard error of the means

SD: standard deviation

DMEM: Dulbecco's modified Eagle's medium

DMSO: dimethylsulfoxide

HEPES: N-2-hydroxyethylpiperazine- $\mathrm{N}^{\prime}$-2-ethansulfonic acid

EGTA: ethylene glycol-bis(B-aminoethyl ether)-N,N,N,N'-tetraacetic acid

ATP: adenosine triphosphate

TTX: tetrodotoxin

IC: intracellular solution (pipette-filling solution)

EC: extracellular solution

PBS: phosphate-buffered saline

iPSC-CM: induced pluripotent stem cell-derived cardiomyocytes APD: action potential duration

\section{Author contributions}

HA and TK conceived the study. OS and BA designed the experiments. MC, BA, VG and OS carried out the research. OS and BA prepared the first draft of the manuscript. HT and HA contributed to the experimental design and preparation of the manuscript. All authors were involved in the revision of the draft manuscript and have agreed to the final content.

\section{Competing interests}

None of the authors has competing interests concerning the present study, except for the participation of TK, OS and BA in the Cytocentrics company.

\section{Grant information}

This study was in part funded by a BMBF grant 03WKCC4D, TransCure NCCR Network to HA, and Austrian Science Fund FWF (grant W1232-B11).

The funders had no role in study design, data collection and analysis, decision to publish, or preparation of the manuscript.

\section{Acknowledgements}

The authors gratefully acknowledge Stefanie Frech, Jörg Eisfeld, Ingrid Rosenkranz, Juliane Böttcher, Christian Scherpeltz, Yassine M. Amarcouch and Jean-Sébastien Rougier for their support, and Cellular Dynamics International for the provision of iCell $^{\circledR}$ Cardiomyocytes.
1. Clancy CE, Tateyama M, Liu $\mathrm{H}$, et al: Non-equilibrium gating in cardiac $\mathrm{Na}^{+}$ channels: an original mechanism of arrhythmia. Circulation. 2003; 107(17): 2233-7.

PubMed Abstract | Publisher Full Text

2. Grandi E, Puglisi JL, Wagner S, et al:: Simulation of Ca-calmodulin-dependent protein kinase II on rabbit ventricular myocyte ion currents and action potentials. Biophys J. 2007; 93(11): 3835-47. PubMed Abstract | Publisher Full Text | Free Full Text

3. Bennett PB, Yazawa K, Makita N, et al.: Molecular mechanism for an inherited cardiac arrhythmia. Nature. 1995; 376(6542): 683-5. PubMed Abstract | Publisher Full Text

4. Bezzina C, Veldkamp MW, van Den Berg MP, et al.: A single $\mathrm{Na}(+)$ channel mutation causing both long-QT and Brugada syndromes. Circ Res. 1999; 85(12): 1206-13.

PubMed Abstract | Publisher Full Text

5. Veldkamp MW, Viswanathan PC, Bezzina C, et al:: Two distinct congenital arrhythmias evoked by a multidysfunctional $\mathrm{Na}(+)$ channel. Circ Res. 2000; 86(9): E91-7. PubMed Abstract | Publisher Full Text 
6. Abriel $\mathrm{H}$ : Cardiac sodium channel $\mathrm{Na}(\mathrm{v}) \mathbf{1 . 5}$ and interacting proteins: Physiology and pathophysiology. J Mol Cell Cardiol. 2010; 48(1): 2-11.

PubMed Abstract | Publisher Full Text

7. Antzelevitch C, Nesterenko V, Shryock JC, et al:: The role of late I Na in development of cardiac arrhythmias. Handb Exp Pharmacol. 2014; 221: 137-68. PubMed Abstract | Publisher Full Text | Free Full Text

8. Grant AO: Cardiac ion channels. Circ Arrhythm Electrophysiol. 2009; 2(2): 185-94. PubMed Abstract | Publisher Full Text

9. Clancy CE, Rudy Y: Linking a genetic defect to its cellular phenotype in a cardiac arrhythmia. Nature. 1999; 400(6744): 566-9. PubMed Abstract | Publisher Full Text

10. Kleber AG, Rudy Y: Basic mechanisms of cardiac impulse propagation and associated arrhythmias. Physiol Rev. 2004; 84(2): 431-88. PubMed Abstract | Publisher Full Text

11. Antzelevitch C, Belardinelli L, Zygmunt AC, et al.: Electrophysiological effects of ranolazine, a novel antianginal agent with antiarrhythmic properties. Circulation. 2004; 110(8): 904-10. PubMed Abstract | Publisher Full Text | Free Full Text

12. Belardinelli L, Shryock JC, Fraser H: Inhibition of the late sodium current as a potential cardioprotective principle: effects of the late sodium current inhibitor ranolazine. Heart. 2006; 92(Suppl 4): iv6-iv14. PubMed Abstract | Publisher Full Text | Free Full Text

13. Undrovinas Al, Belardinelli L, Undrovinas NA, et al:: Ranolazine improves abnormal repolarization and contraction in left ventricular myocytes of dogs with heart failure by inhibiting late sodium current. J Cardiovasc Electrophysiol. 2006; 17(Suppl 1): S169-S77.

PubMed Abstract | Publisher Full Text | Free Full Text

14. Hale SL, Kloner RA: Ranolazine, an inhibitor of the late sodium channel current, reduces postischemic myocardial dysfunction in the rabbit. $J$ Cardiovasc Pharmacol Ther. 2006; 11(4): 249-55. PubMed Abstract | Publisher Full Text

15. Mahesh Kumar KN, Sandhiya S: Ranolazine: A novel partial inhibitor of fatty acid oxidation for angina. Indian J Pharmacol. 2006; 38(4): 302-4. Publisher Full Text

16. Fredj S, Sampson KJ, Liu H, et al.: Molecular basis of ranolazine block of LQT-3 mutant sodium channels: evidence for site of action. Br J Pharmacol. 2006; 148(1): 16-24. PubMed Abstract | Publisher Full Text | Free Full Text

17. Luo A, Ma J, Song Y, et al.: Larger late sodium current density as well as greater sensitivities to ATX II and ranolazine in rabbit left atrial than left ventricula myocytes. Am J Physiol Heart Circ Physiol. 2014; 306(3): H455-61. PubMed Abstract | Publisher Full Text

18. Maltsev VA, Undrovinas Al: A multi-modal composition of the late $\mathrm{Na}^{+}$current in human ventricular cardiomyocytes. Cardiovasc Res. 2006; 69(1): 116-27. PubMed Abstract | Publisher Full Text | Free Full Text

19. Moreno JD, Clancy CE: Pathophysiology of the cardiac late $\mathrm{Na}$ current and its potential as a drug target. $J$ Mol Cell Cardiol. 2012; 52(3): 608-19. PubMed Abstract | Publisher Full Text | Free Full Text

20. Moreno JD, Yang PC, Bankston JR, et al:: Ranolazine for congenital and acquired late $\mathrm{I}_{\mathrm{Na}}$-linked arrhythmias: in silico pharmacological screening. Circ Res. 2014; 113(7): e50-61.

PubMed Abstract | Publisher Full Text | Free Full Text

21. Zaza A, Belardinelli L, Shryock JC: Pathophysiology and pharmacology of the cardiac "late sodium current". Pharmacol Ther. 2008; 119(3): 326-39. PubMed Abstract | Publisher Full Text
22. McKinney LC, Chakraverty S, De Weer P: Purification, solubility, and pKa of veratridine. Anal Biochem. 1986; 153(1): 33-8.

PubMed Abstract | Publisher Full Text

23. Kupchan SM, Lavie D, Deliwala CV, et al.: Schoenocaulon alkaloids. I. Active principles of Schoenocaulon officinale. Cevacine and protocevine. J Am Chem Soc. 1953; 75(22): 5519-24.

Publisher Full Text

24. Dice MS, Kearl T, Ruben PC: Methods for studying voltage-gated sodium channels in heterologous expression systems. Methods Mol Med. 2006; 129 : 163-85.

PubMed Abstract | Publisher Full Text

25. Van Driessche W, Lindemann B: Concentration dependence of currents through single sodium-selective pores in frog skin. Nature. 1979; 282(5738): 519-20. PubMed Abstract | Publisher Full Text

26. Lacerda AE, Kuryshev $Y A$, Chen $Y$, et al:: Alfuzosin delays cardiac repolarization by a novel mechanism. J Pharmacol Exp Ther. 2008; 324(2): 427-33. PubMed Abstract | Publisher Full Text

27. Rajamani S, El-Bizri N, Shryock JC, et al:: Use-dependent block of cardiac late $\mathrm{Na}(+)$ current by ranolazine. Heart Rhythm. 2009; 6(11): 1625-31. PubMed Abstract | Publisher Full Text | Free Full Text

28. Stett A, Burkhardt C, Weber U, et al.: CYTOCENTERING: a novel technique enabling automated cell-by-cell-patch clamping with the CYTOPATCH chip. Recept Chann. 2003; 9(1): 59-66.

PubMed Abstract

29. Catterall WA: Cooperative activation of action potential $\mathrm{Na}^{+}$ionophore by neurotoxins. Proc Natl Acad Sci U S A. 1975; 72(5): 1782-6. PubMed Abstract | Publisher Full Text | Free Full Text

30. Ulbricht W: Effects of veratridine on sodium currents and fluxes. Rev Physiol Biochem Pharmacol. 1998; 133: 1-54. PubMed Abstract | Publisher Full Tex

31. Le Grand B, Pignier C, Letienne R, et al:: Sodium late current blockers in ischemia reperfusion: is the bullet magic? J Med Chem 2008:51(13): 3856-66.

PubMed Abstract | Publisher Full Text

32. Bradley E, Webb TI, Hollywood MA, et al:: The cardiac sodium current $\mathrm{Na}(\mathrm{v}) \mathbf{1 . 5}$ is functionally expressed in rabbit bronchial smooth muscle cells. Am J Physiol Cell Physiol. 2013; 305(4): C427-35. PubMed Abstract | Publisher Full Text

33. Tsuruyama K, Hsiao CF, Chandler SH: Participation of a persistent sodium current and calcium-activated nonspecific cationic current to burst generation in trigeminal principal sensory neurons. J Neurophysiol. 2013; 110(8): 1903-14. PubMed Abstract | Publisher Full Text | Free Full Text

34. Rocchetti M, Sala L, Rizzetto R, et al.: Ranolazine prevents $\mathrm{I}_{\mathrm{Na}} \mathrm{L}$ enhancement and blunts myocardial remodelling in a model of pulmonary hypertension. Cardiovasc Res. 2014; 104(1): 37-48. PubMed Abstract | Publisher Full Text

35. Scheel O, Himmel H, Rascher-Eggstein G, et al:: Introduction of a modular automated voltage-clamp platform and its correlation with manual human ether-à-go-go related gene voltage-clamp data. Assay Drug Dev Technol. 2011; $9(6): 600-7$. PubMed Abstract | Publisher Full Text

36. Chevalier M, Amuzescu B, Gawali V, et al:: Experimental data showing the effect of veratridine, ranolazine and TTX on late $\mathrm{Na}^{+}$currents in cultured cells. F1000Research. 2014

Data Source 


\section{Open Peer Review}

\section{Current Peer Review Status:}

\section{Version 1}

Reviewer Report 29 October 2014

https://doi.org/10.5256/f1000research.5923.r6444

(C) 2014 Fiset C. This is an open access peer review report distributed under the terms of the Creative Commons Attribution License, which permits unrestricted use, distribution, and reproduction in any medium, provided the original work is properly cited.

\section{Céline Fiset}

Research Center, Montreal Heart Institute and Faculty of Pharmacy, Université de Montréal, Montréal, QC, Canada

In this study, Chevalier et al. had succeeded to record and analyse the late $\mathrm{Na}^{+}$current $\left(\mathrm{I}_{\mathrm{NaL}}\right)$ in HEK293 cells stably transfected with wild-type human SCN5A, using automated patch-clamp technology. They were able to accurately assess the effects of pharmacological agents on $\mathrm{I}_{\mathrm{NaL}}$. They showed that the cardiac $\mathrm{I}_{\mathrm{NaL}}$ can be inhibited by ranolazine and activated by veratridine. Using fluctuation analysis, they hypothesized that ranolazine would act as an open pore blocker, reducing the open probability without affecting the number of active channels, while veratridine would increase the number of active channels without influencing their open probability. In addition, they also provided additional functional data by performing a series of automated patchclamp experiments showing that application of veratridine concentrations that increased $\mathrm{I}_{\mathrm{NaL}}$ but had no effects on HERG current prolonged the action potential duration of human iPSC-derived cardiomyocytes.

This is an interesting and well-designed study that reports high quality data. Considering the role of late sodium current in the action potential duration, mainly under pathological conditions, and the difficulty to accurately record this small ionic current, the subject of this study is highly relevant. The demonstration of the suitability of the automated patch clamp technology to accurately measure the late sodium current and to assess the effects of pharmacological agents on this current is helpful. In addition, the use of the hiPSC -derived cardiomyoyctes with this approach is also interesting. I do not have any major issues to address. However, the paper could be improved by attention to the following points.

1. All experiments were performed at room temperature. Considering the limited amplitude of the late $\mathrm{Na}^{+}$current under basal conditions, it could have been useful to perform these experiments at a more physiological temperature to help increase the amplitude of the current.

2. In Figure $1 \mathrm{~B}$, it would have been interesting to also present the recordings with ranolaxine alone. 
3. The action potential was elicited by the injection of $2 \mathrm{nA}$ of current. This is a rather large current and is probably not just-suprathreshold depolarizing current. Do the hiPSC-derived cardiomyocytes usually require such a high current injection to elicit action potential?

4. For the HERG recordings, is there any specific reason why the external concentration of $\mathrm{KCl}$ was only $2.5 \mathrm{mM}$ ?

5. Data reported in Table 1 could have been normalized to the cell capacitance to report the current density instead of the current amplitude.

6. For some statistical analysis, an ANOVA would have been more appropriate that a Student's $t$ tests as several groups were examined (eg., Tables 1 and 2 ).

7. There are few typographic errors in the Abstract: the units for the drugs ranolaxine, veratridine and TTX are all in millimolar concentrations but should be in the micromolar concentrations.

Overall, the study is interesting and describes a methodological approach that could help study the late sodium current. The experiments were well designed and presented and the subject of this manuscript is of importance to the field.

Competing Interests: No competing interests were disclosed.

\section{I confirm that I have read this submission and believe that I have an appropriate level of expertise to confirm that it is of an acceptable scientific standard.}

Reviewer Report 28 October 2014

https://doi.org/10.5256/f1000research.5923.r6442

(C) 2014 Delpon E et al. This is an open access peer review report distributed under the terms of the Creative Commons Attribution License, which permits unrestricted use, distribution, and reproduction in any medium, provided the original work is properly cited.

\section{Eva Delpon}

Facultad de Medicina, Universidad Complutense de Madrid, Madrid, Spain

\section{Ricardo Caballero}

Facultad de Medicina, Universidad Complutense de Madrid, Madrid, Spain

The paper by Chevalier et al. analyzed whether late sodium current $\left(\mathrm{I}_{\mathrm{NaL}}\right)$ can be assessed using an automated patch-clamp device. To this end, the $\mathrm{I}_{\mathrm{NaL}}$ effects of ranolazine (a well known $\mathrm{I}_{\mathrm{NaL}}$ inhibitor) and veratridine (an $\mathrm{I}_{\mathrm{NaL}}$ activator) were described. The authors tested the CytoPatch automated patch-clamp equipment and performed whole-cell recordings in HEK293 cells stably transfected with human Nav1.5. Furthermore, they also tested the electrophysiological properties of human induced pluripotent stem cell-derived cardiomyocytes (hiPS) provided by Cellular Dynamics International. The title and abstract are appropriate for the content of the text. 
Furthermore, the article is well constructed, the experiments were well conducted, and analysis was well performed.

$\mathrm{I}_{\mathrm{NaL}}$ is a small current component generated by a fraction of Nav1.5 channels that instead to entering in the inactivated state, rapidly reopened in a burst mode. $\mathrm{I}_{\mathrm{NaL}}$ critically determines action potential duration (APD), in such a way that both acquired (myocardial ischemia and heart failure among others) or inherited (long QT type 3) diseases that augmented the $\mathrm{I}_{\mathrm{NaL}}$ magnitude also increase the susceptibility to cardiac arrhythmias. Therefore, $\mathrm{I}_{\mathrm{NaL}}$ has been recognized as an important target for the development of drugs with either antiischemic or antiarrhythmic effects. Unfortunately, accurate measurement of $\mathrm{I}_{\mathrm{NaL}}$ is a time consuming and technical challenge because of its extra-small density. The automated patch clamp device tested by Chevalier et al. resolves this problem and allows fast and reliable $\mathrm{I}_{\mathrm{NaL}}$ measurements.

The results here presented merit some comments and arise some unresolved questions. First, in some experiments (such is the case in experiments B and D in Figure 2) current recordings obtained before the ranolazine perfusion seem to be quite unstable. Indeed, the amplitude progressively increased to a maximum value that was considered as the control value (highlighted with arrows). Can this problem be overcome? Is this a consequence of a slow intracellular dialysis? Is it a consequence of a time-dependent shift of the voltage dependence of activation/inactivation? Second, as shown in Figure 2, intensity of drug effects seems to be quite variable. In fact, experiments $A, B, C$, and $D$ in Figure 2 and panel 2D, demonstrated that veratridine augmentation ranged from $0-400 \%$. Even assuming the normal biological variability, we wonder as to whether this broad range of effect intensities can be justified by changes in the perfusion system. Has been the automated dispensing system tested? If not, we suggest testing the effects of several $\mathrm{K}^{+}$ concentrations on inward rectifier currents generated by Kir2.1 channels $\left(\mathrm{I}_{\text {Kir2.1 }}\right)$.

The authors demonstrated that the recording quality was so high that the automated device allows to the differentiation between noise and current, even when measuring currents of less than $5 \mathrm{pA}$ of amplitude. In order to make more precise mechanistic assumptions, the authors performed an elegant estimation of current variance $\left(\sigma^{2}\right)$ and macroscopic current (I) following the procedure described more than 30 years ago by Van Driessche and Lindemann ${ }^{1}$. By means of this method, Chevalier et al. concluded that ranolazine acts as an open pore blocker reducing the open channel probability, while veratridine increases the number of channels in the burst mode. We respectfully would like to stress that these considerations must be put in context from a pharmacological point of view. We do not doubt that ranolazine acts as an open channel blocker, what it seems clear however, is that its onset block kinetics has to be "ultra" slow, otherwise ranolazine would decrease peak $\mathrm{I}_{\mathrm{NaL}}$ even at low frequencies of stimulation. This comment points towards the fact that for a precise mechanistic study of ionic current modifying drugs it is mandatory to analyze drug effects with much more complicated pulse protocols. Questions thus are: does this automated equipment allow to the analysis of the frequency-, time-, and voltagedependent effects of drugs? Can versatile and complicated pulse protocols be applied? Does it allow to a good voltage control even when generated currents are big and fast? If this is not possible, and by means of its extraordinary discrimination between current and noise, this automated patch-clamp equipment will only be helpful for rapid $\mathrm{I}_{\mathrm{NaL}}$-modifying drug screening. Obviously it will also be perfect to test HERG blocking drug effects as demanded by the regulatory authorities.

Finally, as cardiac electrophysiologists, we would like to stress that it seems that our dream of 
testing drug effects on human ventricular myocytes seems to come true. Indeed, human atrial myocytes are technically, ethically and logistically difficult to get, but human ventricular are almost impossible to be obtained unless from the explanted hearts from patients at the end stage of cardiac diseases. Here the authors demonstrated that ventricular myocytes derived from hiPS generate beautiful action potentials that can be recorded with this automated equipment. The traces shown suggested that there was not alternation in the action potential duration. Is this a consistent finding? How long do last these stable recordings? The only comment is that resting membrane potential seems to be somewhat variable. Can this be resolved? Is it an unexpected veratridine effect? Standardization of maturation methods of ventricular myocytes derived from hiPS will be a big achievement for cardiac cellular electrophysiology which was obliged for years to the imprecise extrapolation of data obtained from a combination of several species none of which was representative of human electrophysiology. The big deal will be the maturation of human atrial myocytes derived from hiPS that fulfil the known characteristics of human atrial cells.

\section{Minor points:}

We suggest suppressing the initial sentence of section 3 . We surmise that results obtained from the experiments described in this section cannot serve to understand the role of $\mathrm{I}_{\mathrm{NaL}}$ in arrhythmogenesis.

\section{References}

1. Van Driessche W, Lindemann B: Concentration dependence of currents through single sodiumselective pores in frog skin.Nature. 1979; 282 (5738): 519-520 PubMed Abstract | Publisher Full Text

Competing Interests: No competing interests were disclosed.

We confirm that we have read this submission and believe that we have an appropriate level of expertise to confirm that it is of an acceptable scientific standard. 
The benefits of publishing with F1000Research:

- Your article is published within days, with no editorial bias

- You can publish traditional articles, null/negative results, case reports, data notes and more

- The peer review process is transparent and collaborative

- Your article is indexed in PubMed after passing peer review

- Dedicated customer support at every stage

For pre-submission enquiries, contact research@f1000.com 